\title{
THE PUBLIC BANK RESURGENT: PROSPECTS OF DEMOCRATIZATION FOR SUSTAINABLE DEVELOPMENT
}

\author{
Thomas MAROIS ${ }^{1}$
}

Public banks are resurgent, triggered by the failure of private finance to meaningfully confront the green transformation. But will resurgent public banks act in the public or private interest? How can progressives ensure public banks support a just green transformation? Democratization is the key.

The resurgent turning point for public banks was really the UN's 2015 Addis Ababa Action Agenda on how to finance the 2030 Sustainable Development Goals (SDGs). The international community finally acknowledged what most already knew: private finance had no appetite for saving the planet without first feeding insatiable shareholders. Ergo, high-risk, low-return green investments weren't on the menu.

The solution? For the UN, the World Bank, and the OECD it is to subordinate public finance to private interests. Public development banks should take the lead in absorbing private investors' risks to guarantee their projected returns. There is no other way of cajoling otherwise reticent financiers to fund the global transition to a low-carbon, climate resilient future. Besides, public banks have limited financial capacity. The green transition needs the seemingly unlimited pools of global financial capital. This is the core message of the UN's Inter-Agency Task Force 2019 Financing for Sustainable Development Report, with an important sub-text being public financial incapacity. Reinforcing existing neoliberal tropes, there is no alternative but to mobilise private finance for climate finance. The nuanced message being we now need public finance to underwrite it.

But what if this wasn't true, or at least not in the way pitched by neoliberal ideologues and unhindered growth advocates? A new edited book by the Transnational Institute (Amsterdam), Public Finance for the Future We Want, paints a different picture. The contributors evidence the many ways that the future of finance can and should be public, backed by real-world examples of alternatives spanning the globe. However, the structural power of global predatory finance must be curbed in order to build the basis for a democratically-organised and life-sustaining future. Public finance must enable the public, not private, interest.

\section{Public Banking Power}

Public banks, in particular, are shown to have much greater financial capacity than commonly believed. Whereas the IATF 2019 Report claims there is only \$5 trillion in combined public bank assets (so, hardly sufficient to tackle the $\$ 4$ to $\$ 6$ trillion in additional annual climate

1 Dr., Senior Lecturer of Development Studies, SOAS University of London \& the Municipal Services Project, tm47@soas.ac.uk 
mitigation investments by 2030), the TNI contribution demonstrates that there are nearly 700 public banks around the world that have combined assets nearing $\$ 38$ trillion (that's about 48 per cent of global GDP). Put otherwise, 20 per cent of all bank assets are still publicly owned and controlled.

This accounts for just the national and sub-national banks. Examples span the globe from the well-known French La Caisse des Dépôts and the China Development Bank to the lesser-known Vietnam Bank for Social Policies and the Turkish Ilbank (Provinces bank). If you add in the stateowned multilateral development banks (like the World Bank) plus public pension and sovereign wealth funds plus central banks, then total combined public financial assets jump to just under $\$ 74$ trillion. Given political will and popular support - something of the kind envisioned in the Green New Deal - public financial capacity can be rapidly scaled-up and mobilised.

If we go blindly down the current UN-authenticated climate finance path, existing public banking capacity is at serious risk of being captured by private financial interests. Should this occur, private investors' profit- and growth-driven imperatives will undermine any hope of a just and green transformation in the public interest. Moreover, public finance will only feed the very same private financiers that contributed to the climate finance crisis in the first place! Only in a neoliberal world does this make for coherent policy-making.

One alternative solution is to democratize public banks, thus enabling the mobilisation of public bank resources for a just and green transformation in the public interest.

\section{Democratizing Public Banks - The Costa Rican Example}

There are already-existing models of democratization. At a minimum, most public banks' Boards of Directors will include some combination of government ministers and appointed representatives from the community. For example, the modest North American Development Bank (NADB) has a 10-member Board made up mostly of government representatives while the massive German development bank, the KfW, has a much more inclusive 37-member Board with wide ranging societal representation.

The most inspiring model is the Costa Rican 'Banco Popular' (Banco Popular y de Desarrollo Comunal). Its model of democratization can enrich debate on financial alternatives for a green and just transformation. Founded by the government in 1969, the Banco Popular operates under public law as a 'worker-owned' bank geared towards serving the 'collective welfare' of society. By law, Costa Rican workers must deposit 1.5 per cent of their wages into the Banco Popular. After a year, 1.25 per cent of their contribution is transferred to the worker's pension fund. The remaining 0.25 per cent is held in the bank as a form of permanent capitalization to support mandated lending programmes.

The workers' contributions come with meaningful representation. In 1986 the Banco Popular firmly institutionalised democratization procedures by creating the 'Assembly of Working Men and Women' and making it the bank's highest decision-making forum. Representatives from across ten social and economic sectors constitute the 290-member Workers' Assembly. According Carlos Cortés, Costa Rican writer and reporter, the Workers' Assembly is the corner stone of the bank's contribution to the democratization of Costa Rica's economy, development, and financial system. 
Within the Assembly, the Permanent Commission for Women holds the Assembly accountable for gender equity. Across the bank as a whole, the Banco Popular is required to have 50 percent representation of women present in all decision-making bodies. The Women's Commission holds the bank accountable to this, while building gender equity capacity and awareness. Gender equity requirements extend to local representative councils linked to the bank's nationwide branch network.

In the Banco Popular, the Board of Directors is subordinate to the Assembly. The Board is, nevertheless, where many key operational decisions are taken - so it too is democratized. The seven-member National Board of Directors is made up of three government representatives and four elected Worker's Assembly representatives.

These achievements are not taken for granted. In 2002, Costa Ricans passed a legal reform, the 'Democratization' Law (No. 8322 Ley de Democratización de las Instancias del Decisión del Banco Popular y de Desarrollo Comunal). The Law, probably unique in the world of finance, re-affirmed and further specified the social purpose, democratic ethos, and gender equity dynamics of the Workers' Assembly and the Banco Popular as an institution.

\section{Finance for The People}

The take-away lessons? Contrary to the prevailing climate finance narrative, we have (and can build) massive public bank financial capacity globally. Moreover, we have the potential to meaningfully democratize public banks via a 'People's Assembly', 'Women's Commissions' (among others), local 'Councils', and representative 'Boards'. We have here a solid starting point for debate on how to finance a just and green transition in ways that are not, first and foremost, bent to the needs of global finance, capital accumulation, and growth imperatives.

In a financialized world dominated by a powerful, unaccountable, and self-interested financial class, there will be no just or green transformation without first reclaiming financial capacity in the public, not private, interest. But it would be a grave mistake to assume that resurgent public banks, by virtue of being publicly-owned, will necessarily function in the public interest. Public banks can and do go wrong. For public banks to work in the public interest, they must be made to do so. This demands meaningful democratization. This is the action now needed. 


\title{
THE PUBLIC BANK RESURGENT: PROSPECTS OF DEMOCRATIZATION FOR SUSTAINABLE DEVELOPMENT
}

\author{
Aslıhan ÖZEL ÖZER ${ }^{1}$
}

\author{
Kayhan ÖZEL²
}

\begin{abstract}
The termination of private-law based labor contracts has been elucidated within a stringent base of forms and conditions whether they be located within Labor Code No:4857, be it Marine Labor Code No:854; or be it the Legislation for the Press-related employer-employee relationship no:5953. Nevertheless, the theme work-related security, in the aftermath of found its place in or legal framework in the lateral stages to have proceeded as a nonexistent term which legal decision makers have opted for not dealing mutual recession which gives the chance to terminate labor contract on a mutual basis, has come onto the stage and entered and consolidated into the implementation decisions of Court of Cassations in Turkey.

These kinds of contracts foresee the termination of the contract by means of the payment of payment in lieu of notice and seniority indemnity or the payment of the very identical compensation items coupled with a lump sum payment of two to eight salaries of the employees. It has long been debated about the matter whether of the payment of payment in lieu of notice and seniority indemnity items may be subject to income tax or not. The response by the expertise has been exposed such that the concerning items may be very well subject to taxation as they have not been juxtaposed within exceptional cases items put forth by the Legislation No: 192 paving the way to making of Department of Taxation's decision on the related matters and cases. However, Courts of Taxation' and council of State's have contrastingly pointed out that the payments shall not be subject to taxation as they can be considered within the exceptions given forth and juxtaposed in the Income Taxation Law, No:193, Article 61.

The Legislation No:7103 has commenced to regulate the concerning mutual recession matters upon the increasing number of related cases and clearly spelled out the required concession in regard to the matter. By means of the Legislation No: 7162's newly adding the provisional article No:189 into the Legislation No:193, the jurisdiction has granted the chance for the reimbursement of income taxation paid out of the related compensation in the period before March 7th, 2018. Given the framework above, this study strives to shed light upon the problems and remedies for the cases confronted in regard to taxation exceptions about mutual recession along with the principles discussed above.
\end{abstract}

Keywords: Mutual Recession, Work Security, Income Tax,Payment in lieu of Notice and Seniority Indemnity, Reasonable Benefit, Tax Deductions, Tax Deduction, Tax Cut

JEL Code: H24, H26, J3, K31.

\footnotetext{
1 Asst. Prof. Dr., Manisa Celal Bayar University, Ahmetli Vocational School, Accounting and Tax Application Programme, aslihanozel@yahoo.com

2 Lawyer, Retired Chief Supervisor, Ministry of Labour, Social Services and Family, kayhanozel@gmail.com
} 


\section{Introduction}

The very problematization in regard to whether the mutual termination of labor contract known as mutual recession shall be subject to tax or not along with other deductions has been a heated debate since its inception. According to one strand of literature, such kind of payments are in the form of the payment of payment in lieu of notice and seniority indemnity items shall be subject to income law along other related deductions that are related to Social Security Institution. Another strand of literature in the meanwhile argues that these payments are monetary compensation items due to the termination of labor contracts they shall net be subject to any regulations. Indeed, there has been a wide sense of discrepancy in the implementation of these payment in lieu of notice and seniority indemnity items from de jure and de facto practices, legal cases have come to emerge in regard to these different practices and evaluations of the law, leading to the regulation of these cases by Legislation Number 7103 and 7162.

Due to the high frequency of cases submitted to legal reviews, it becomes a necessity to put the issue under scrutiny. In such regard, this study strives to shed light upon the problems and remedies for the cases confronted in regard to taxation exceptions about mutual recession along with the principles discussed above.

\section{Definition and Content of Contracts of Mutual Recession}

Recession refers to the claim that an unstated theme has been mentioned literally while the term in a de jure sense refers to the fact that an existing contract comes to be terminated with the mutual consent of regarding parties (Sarı Mustaoğlu, 2011: 4). Being a term of the law of Obligations along with the fact that term is not a component of jurisdictions and the term has become a popular implementation within the private law, the mutual recession has come to function as a work security measure in the Law Number 4773 dated March 15th 2003 amending the Law Number 1475 dated June 10th 2003 Article Number 13 regulating the former regulating companies with 30 employees and the latter regulating the companies with 10 employees. The very pretext for work security can be traced back to the "Contract 158 in regard to termination of Work Contracts by Employers" by International Labor Organization that comes to be a formal part of domestic Law with the approval of the aforementioned contract by Turkish Grand National Assembly on June 9th, 1994

This remedy aiming to provide the compensatory items like payment in lieu of notice and seniority indemnity for the employees intending to leave their jobs and to grant the employers that cannot surpass several complications regarding the legal termination of labor contracts within the relevant and laws with the desire not to meet the material and non-material responsibilities due to the legal decision of courts for the return of employees back to their jobs has been a soft handed solution designed legally with the support of Court of Cassations, assuming a very important mechanism within our domestic law. The regulations put forth by the Court of Cassations see it as a necessity for the mutual recession cases such that "should the demand come from employees only payment in lieu of notice and seniority indemnity and should the demand come from employer's extra benefits along with the aforementioned compensatory items reasonable benefits should be granted to the affected parties (Yargıtay 9. HD. 09.11.2017 tarih ve 2016/28986 Esas, 2017/17897 Karar sayılı kararı) 
The employees taking advantage of mutual recession mechanism shall not be a beneficiary of unemployment benefits along with the work security themes in the contract. Consequently, a reasonable benefit should be provided for employees. The reasonable benefits have been decided to a be lump-sum payment of four-months of his or her wages.

\section{Problems Experiences in the Implementation of Mutual Recession Contracts}

In the aftermath of implementation of mutual recession contract, the view of the administration has been such that the compensatory payments shall be subject to taxation after the deduction of the amount equal to payment in lieu of notice and seniority indemnity as stated in the Legislation Number 1475 as explained in the regulatory note Number GVK 94-53 dated December 15the 2010as put forth by the Income and Revenues Administration, the Tax Administration of Macro Taxpayers. The ides have been to subject the compensatory items partially

Regulation circumstances and conditions regulating payment in lieu of seniority indemnity are explicitly stated in the 14th Article. Yet when the situation boils down to the point that while behalves mutually are consenting to the termination of contract, the benefits as compensatory items shall not be considered to be payment in lieu of seniority indemnity legally. In a de jure sense a payment that cannot be deemed to be payment in lieu of seniority indemnity shall come in contradiction with the decision of the administration stating that payment in lieu of notice shall be consider as wages along with the regulation of Law Number 193 Article $25^{\text {th }}$ emphasizing that payment in lieu of seniority indemnity is also inclusive in the process.

Yet the Judiciary reviews have been somewhat different in the sense that a subject of taxation for these compensatory items is not valid on the grounds that "according to the 6th article of Income and Revenues Law Number 193 wages and so-wage accepted payments are those payments arising from the fidelity of employees in exchange of their services, monetary and non-monetary in kinds yet only deductions can be realized through wage or wage-kind payments. Compensation due to the termination of contracts owing the downsizing of the firms compensation shall not be matter of subjection to taxation as these payments do not carry the characteristics of a wage and wage-related payment therefore that these payment cannot be a matter of source of taxation therefore the carried out decisions should be considered to be illegal as stated by Istanbul 5th Tax Court dated December 12th 2013 Number 2013/2099 as confirmed with the appeal decision of the Council of State Department Number 4 dated December 13th 2016 Number 4376 with the opposition of a single vote thereby indicating that the debate has come to an end and all payments in regard to the mutual recession contracts shall ne to be subject to any taxation whatsoever.

\section{Legal Regulations}

The court's decision to return all the paid and directed tax payments has led the decision makers to legally regulate upon the matter and attempted to resolve the matter by the Law Number 7103 , however the laws was less than capable of solving the matters in regard to the mutual recession contract problematizations.

By means of Law Number 7103 to amend some components of laws and decrees dated March 28th 2018 that amended the 61th Article of Law Number 193 such that mutual recession 
contract related compensatory items including loss of job compensations, termination work compensations, work security compensations shall be considered to be wages, therefore rendering the decision of the Judiciary ungrounded

On the other hand, the 21st Article of Labor Code Number 4857 compensation avoiding the return of employees to work has already underlined the need to exempt of all compensatory from taxation

In the meanwhile, The A subparagraph of the 7th paragraph remaking the 25th Article of Legislation Number 193 has maintained all regulations unchanged the amounts to be paid for payment in lieu of seniority indemnity according to the Laws Number 1475, 854 and 5953. As regulated, the ceiling for payment in lieu of seniority indemnity by Law Number 1475 and 854 shall not exceed the annually paid amount for the retirement compensation paid highest ranks of civil servant subject to Civil Servant Code Number 657. The ceilings have been indicated by the Table 1.

Table 1. Maximum Retirement Compensation for the highest Ranks of Civil Servants (2014-2019, TL)

\begin{tabular}{|c|c|}
\hline INTERVAL & AMOUNT \\
\hline $01.01 .2019-30.06 .2019$ Period & $T L 6.017,60$ \\
\hline $01.07 .2018-31.12 .2018$ Period & $T L 5.434,42$ \\
\hline $01.01 .2018-30.06 .2018$ Period & $T L 5.001,76$ \\
\hline $01.07 .2017-31.12 .2017$ Period & $T L 4.732,48$ \\
\hline $01.01 .2017-30.06 .2017$ Period & $T L 4.426,16$ \\
\hline $01.07 .2016-31.12 .2016$ Period & $T L 4.297,21$ \\
\hline $01.01 .2016-30.06 .2016$ Period & $T L 4.092,53$ \\
\hline $01.09 .2015-31.12 .2015$ Period & $T L 3.828,37$ \\
\hline $01.07 .2015-31.08 .2015$ Period & $T L 3.709,98$ \\
\hline $01.01 .2015-30.06 .2015$ Period & $T L 3.541,37$ \\
\hline $01.01 .2014-31.12 .2014$ Period & $T L 3.438,22$ \\
\hline
\end{tabular}

Source: Yaklaşım Yayıncılık, Kıdem Tazminatı Tavanı, http://www.yaklasim.com /BookList.aspx?Announcementld=2810\&AnnouncementCategoryld=8\&_ (11.01.2019)

The pre-Law Number 7103 and post Law Number 7103 tax exemption rates have been quite different. The exemption before the aforementioned law that is to say before March $28^{\text {th }} 2018$ the exemption was equal to the payment in lieu of seniority equivalent to the employer's very recent wage. Concretely speaking the pre -law regulation stipulates the TL 2000 tax cut in the case of payment of TL 6000 for the payment of lieu of seniority while the tax exemption with all added wage payments for the employees have been determined as TL 4000 under the payment of lieu of seniority in the post Law era, provided that the payment in lieu of seniority payment is TL 6000, by means of ceilings of 2018 determined around TL 5001,76, a tax cut amount of TL 998,24 will be applied. Henceforth an opportunity of payment in lieu of seniority up to seniority compensation ceiling shall be possible without a tax cut. 


\subsection{Exception in the Mutual Recession Contracts}

The law Number 7103 regulating the Law Number 193 Article 25 Paragraph Number 1 and subparagraph 7/B underlined the need to take under payment of seniority exemption rates depending on the jurisdictions that employers are located within. In more clear words, whilst calculating the exemption rates that employees will be granted from income by the aforementioned laws mutually recessed contracts and such related mutual agreements shall be inclusive of compensatory items included in the agreements along loss job compensation, termination of work and work security compensations and henceforth deductions shall be realized over the total amount payments to be realized over the ceiling rates. All those amounts exceeding the ceiling shall be levied taxes.

The General Declaration Income Tax published in the Official Gazette Number 30448 dated June $11^{\text {th }} 2018$ as stated in the Serial Number 303/3 in case of extra compensation payments outside of the seniority payments based on the Law Number 1475 Labor Code and Law Number 857 Maritime Labor Code both payments will be paid with the deduction from ceiling rates and the rest of the amount shall be subject to taxation. In the case Law Number 5953 Press Employees and Employers Regulation popularly as known as Press Labor Code in the case of extra payment of compensation of seniority both amounts shall be added and exemptions shall be granted to the equivalent of 24-month of recent wage. The remaining rest shall be a matter of taxation. In the case of payments under different names other than the compensation of seniority and indemnity the ceiling rated of law Number 1475 and 854 and the 24-month wage equivalent of Law Number 5953 shall be taxied. Several examples have also been put forth in the Official Declaration aforementioned.

The law-makers have determined the exemption rates for the possible abuses and henceforth have implicitly accepted that these compensatory item shall be exempt from taxation

Law Number 7103 puts an end to those debates in regard to the different legal matters involving the compensations in lieu of notice and seniority and indemnity to avoid conflicts with the decisions of the courts and the administration with the objective of minimizing tax losses. Notwithstanding the mentioned law, those parties appealing for the return of taxation paid before March $28^{\text {th }} 2018$ have still the right to file and can file their cases in the Tax Courts.

\subsection{Other Exemptions Granted}

Under the condition that they are stated within the framework of the declaration $4 \mathrm{~b}$ and annulled 4c-framwork public employee2 compensations of the Civil Servants Law Number 657 shall also be tax exempted along the directives of the above section's analysis

\subsection{Recent Regulations}

For those actions accrued out in the pre March 28 2018 tax the Law Number 7162 dated December 30th 2019 has juxtaposed measures to deal with the existing conflicts

In the Provisional Article 86 added with the fourth article of Taxation Law Number 716 with Income and Revenue Law Number 193, it is stated as such 


\begin{abstract}
"As a source all sums of income payments of taxation due to the compensations done before March $27^{\text {th }} 2018$ with the mutually-ended or mutually recessed contracts under heading of loss of work, end of work, work security related payments shall be annulled and returned upon the direct application of the behalves within the time limits indicated to the Tax Courts that have the right to direct tax and upon the waiver of the existing legal cases versus the Administration based on the corrective measures of Tax Procedure Law Number 213

For the quitted cases versus the administrations, the judiciary costs and representation fees shall also be quitted

For those cases whose final verdicts have granted by courts the provision shall not apply

All regulatory measures shall be applied by the Treasury Ministry and Ministry of Finance in terms of procedures and by-laws.
\end{abstract}

Ministry of Finance did the necessary regulations with the Declaration on Income and Revenue Tax dated March $15^{\text {th }} 109$ with the Serial Number 306. Accordingly a source all sums of income payments of taxation due to the compensations done before March $27^{\text {th }} 2018$ with the mutuallyended or neutrally recessed contracts under heading of loss of work, end of work, work security related payments shall be annulled and returned upon the direct application of the behalves within the time limits indicated to the Tax Courts that have the right to direct tax and upon the quittal of the existing legal cases versus the Administration based on the corrective measures of Tax Procedure Law Number 213. The procedure shall commence with the petitions of the related behalves documenting payroll documents relevant for the tax cut period and the mutually recessed agreement. It is important the employees be to have paid for the tax

In the general declaration aforementioned other compensatory measures indicated in the payroll document items taxed of the employee not having the characteristics of compensations such as normal payment, shift payment, official holiday payment, annual leave payment, transfer payments, social security premiums done for the before and existing periods shall not be a matter of tax -return

Extra compensatory measures done after March $27^{\text {th }} 2018$ shall also not be matter of tax-return with the emphasis that it will be impossible to pay the taxes charged after the specific period. Finally, taxes-returned in the aftermath of judicial deliberation shall also be returned with fines and interests levied

The time limit specified for specific corrective time lapse is essential to be noted. The corrective time lapse shall be realized according to the provisions of 114 of the Tax Procedure Law number 213 with reference to 216 in the aftermath of imposition, realization and declaration is five years. For those applications before the March $28^{\text {th }}, 2018$ not exceeding over 5 years of its commencement with deductions after January $1^{\text {st }} 2015$, it will be possible to return the levied tax without any judicial reviews 


\section{Conclusion}

Debates surrounding the point whether payments arising from the mutual recession pf labor contract can be a matter of taxation and can be subject to taxes have been put forth since the inception of these contracts with necessary legal and academic background to be able to comprehend the nature of discussions. In such regard at initial stages tax courts have decided in favor of non-taxation of the payments due to mutual recession contracts based upon the Notion that these items are the-end of-the work compensation as indicated in 25/7 of Turkish Income Law. Appeals to tax these items have been rejected by Council of State, thereby refusing appeals of the administrations. The finalized verdict of the Council of the State led the decision makers to regulate the matter with a different legal framework and limited the exceptions by the Law Number 7103, henceforth attempting to minimize the tax losses. The upper limit of the payment in the lieu of seniority and indemnity has been accepted as an amount for the exemptions to be applied on extra payments due to mutual recession of contracts. Therefore, the stated upper limit has become a containment after which a matter of taxation can be realized through.

The expansion of judicial conflicts in the aftermath of the regulation, a new amendment of Law Number 7162 by means of 193th Article added a provisional matter paved the way of possible rebates or the payments of the contracts realized before March 27th, 2018, whose concrete procedures have been put forth by the Ministerial Discretion Number 306. The tax administration as the study argues, has attempted to minimize tax losses by redeeming the extra payments due to mutual recession and contracts i.e. End of work compensations, seniority payments taxation which are explicit ones like the wages and other payments that can be a matter of discussion into a general framework of taxation. Consequently, the problem seems to be resolved for the tax returns from the beginning of the year 2014 to March 27th 2018.

The very final state of such an implementation has to elucidated and discussed from the point of fairness and equity. The fact that items declared by the Income Law as explicitly nontaxable items were forced legally to be taxable items through a weird sense of calculation of the seniority payments by the administration to create $s$ a sense of justice, thereby making the procreation of taxation, does not appear to be just and comprehensible. Tax-maximization should not be the sole aim of the administration. Another consideration may be such that mutual recessions not involving seniority payments shall not be compatible with the content of the law. In other words, employers shall resort to tax the compensatory item even for those contracts not involving seniority payments.

On other view may conclude with considerations about the constitutionality of the law, thereby bringing the concerning law's creation of unconstitutional and unlawful tax. Until now no application has been made yet given the severity of discussion, the case may be taken to the Constitutional Court with high chance of the annulment of the law.

Finally, it will be the suggestion of the work that in case of taxations creating conflict between the behalves, tax courts shall come to reject the case in favor of employers. 


\section{References}

1475 Sayılı İş Kanunu. (25.08.1971). Resmi Gazete (Sayı: 13943) Erişim Adresi: http://www. mevzuat.gov.tr/MevzuatMetin/1.5.1475.pdf

193 Sayılı Gelir Vergisi Kanunu. (31.12.1960). Resmi Gazete (Sayı: 10700). Erişim Adresi: http:// www.mevzuat.gov.tr/MevzuatMetin/1.4.193.pdf

213 sayılı Vergi Usul Kanunu (04.01.1961). Resmi Gazete (Sayı: 1073-1074-1075) Erişim Adresi: https://www.mevzuat.gov.tr/MevzuatMetin/1.4.213.pdf

306 Seri No'lu Gelir Vergisi Genel Tebliği. (15.03.2019). Resmi Gazete (Sayı: 30715) Erişim Adresi: https://www.gib.gov.tr/node/137674

4857 Sayılı İş Kanunu. (22.05.2003). Resmi Gazete (Sayı: 25134) Erişim Adresi: http://www. mevzuat.gov.tr/MevzuatMetin/1.5.4857.pdf

7103 Sayılı Vergi Kanunları ile Bazı Kanun ve Kanun Hükmünde Kararnamelerde Değişiklik Yapılması Hakkında Kanun. (27.03.2018). Resmi Gazete (Sayı: 30373 ( Mükerrer)). Erişim Adresi: http://www.resmigazete.gov.tr/eskiler/2018/03/20180327m2-1.htm

7162 Sayılı Gelir Vergisi Kanunu ile Bazi Kanunlarda Değişiklik Yapilmasina Dair Kanun (18.1.2019). Resmi Gazete (Sayı: 30671) Erişim Adresi: http://www.resmigazete.gov.tr/ eskiler/2019/01/20190130-6.htm

Danıştay 4. Dairesi 13.12.2016 tarih ve 2014/3676 Esas No., 2016/4376 Karar No. Kararı

Gelir İdaresi. Büyük Mükellefler Vergi Dairesi Başkanlığı. (2010). GVK 94-53 Sayılı Özelgesi http:// www.gib.gov.tr/node/91501 (20.11.2018)

Hizmet İlişkisine İşveren Tarafindan Son Verilmesi Hakkında 158 sayılı ILO Sözleşmesi. http:// www.ilo.org/ankara/conventions-ratified-by turkey/WCMS_377301/lang--tr/index.htm, (25.11.2018).

Mustaoğlu Sarı, N. (2011). Türk Iş̧ Hukukunda İkale Sözleşmesi, Bahçeşehir Üniversitesi Sosyal Bilimler Enstitüsü, (Yayımlanmamış Yüksek Lisans Tezi), İstanbul.

Yaklaşım Yayıncılık (2019) Kıdem Tazminatı Tavanı. http://www.yaklasim.com/ BookList.aspx?Announcementld=2810\&AnnouncementCategoryld=8\&_(11.01.2019)

Yargıtay 9. Hukuk Dairesi. 09.11.2017 tarih ve 2016/28986 Esas, 2017/17897 Karar Sayısı. https:// karararama.yargitay.gov.tr/YargitayBilgiBankasilstemciWeb/ (20.11.2018) 